\title{
This is a pre-print
}

To cite this article: Marijke Verpoorten (2020): How Many Died in Rwanda?, Journal of Genocide Research, DOI: 10.1080/14623528.2019.1703253

\section{How Many Died in Rwanda?}

Marijke Verpoorten

University of Antwerp

\section{Address}

IOB - Institute of Development Policy

University of Antwerp

Prinsstraat 13

2000 Antwerpen

Email: marijke.verpoorten@uantwerp.be

Website: https://www.uantwerpen.be/en/staff/marijke-verpoorten/my-website/

\section{Bio}

Marijke Verpoorten is Associate Professor at the Institute of Development Policy (IOB), University of Antwerp. She uses econometric tools to answer cause and effect questions. Her research deals with the economic causes and consequences of armed conflict; natural resources, religion, global supply chains; and more broadly, with the economic and institutional development of Sub-Saharan Africa, with a special focus on Rwanda, Benin and DR Congo.

\section{Acknowledgements}

I received helpful comments from Bert Ingelaere and Jos van Oijen. All opinions expressed and any errors remain my own. 
From April to July 1994, Tutsi in Rwanda were indiscriminately targeted in a genocidal campaign that was orchestrated by hard liners within the then Hutu-dominated government, and that was executed by the Rwandan Armed Forces, the Presidential Guard, national police, youth militia as well as ordinary Hutu citizens. The genocide against the Tutsi in Rwanda is a well-established fact. Its death toll remains however debated. In this note I explain why there is no consensus; present data to further inform the debate; and argue why I think a range of $560,000-660,000$ Tutsi death is plausible.

Prior to, during and after the 1994 genocide against the Tutsi, other forms of violence took place in Rwanda, and against Rwandans who had sought refuge abroad. These other forms mainly concern:

1. targeted killings of Hutu 'moderates' by Hutu extremists during the 1994 genocide against Tutsi;

2. Hutu and Tutsi battle deaths and civilian casualties of the 1990-94 civil war between the Forces Armées Rwandais (FAR) and the Rwandan Patriotic Army (RPA);

3. killings of Hutu civilians by the RPA as they established control over the Rwandan territory in 1994; and during the closure of internal refugee camps in 1994-95.

4. killings of Hutu and Tutsi in the context of the insurgency and counter-insurgency operations in North-West Rwanda during the period 1995-98, both by the RPA and Hutu insurgents (crossing the border with Congo);

5. killings of Hutu refugees in DR Congo by the RPA in 1996-97.

How to classify these killings, in particular the latter three, is part of an unsettled debate. It also remains impossible to establish a reliable death toll of these killings. Instead, I will make an attempt to estimate how many Hutu lives were lost in the 1990s, either as a direct result of violence, either indirectly, following the rapid spread of contagious diseases in refugee 
camps, and the dire war conditions. I arrive at a guestimate of 542,000, surrounded by a very large uncertainty interval.

\section{How Many Tutsi Died?}

The estimates on the death toll of the 1994 genocide against Tutsi range from a low of 200,000 that featured in the BBC documentary 'Rwanda's Untold Story', ${ }^{1}$ to a high of 1,070,014 according to Rwanda's National Commission for the Fight against Genocide. ${ }^{2}$ The lowest estimate is taken from the $206,000-376,000$ range that was presented on the genodynamics website. ${ }^{3}$ The highest estimate is not part of a range, but the outcome of a victim count in 2000 by the Rwandan Government. ${ }^{4}$ Estimates that are part of scholarly publications lie in between this low and high. They start from two sub questions: (1) How many Tutsi lived in Rwanda at the eve of the genocide? (2) How many Tutsi survived?

The latest publicly available information on the number of Tutsi living in Rwanda prior to the genocide dates from the 1991 population census. The census counts $7,099,844$ Rwandan nationals, among which 597,459 Tutsi, or 8.42 per cent of the population. ${ }^{5}$ Proceeding with rounded figures, and taking into account an average annual population growth of 2.5 per cent in the period August 1991-July 1994, the number of Tutsi, under the no-genocide scenario, would have been 643,000 at the end of July $1994 .^{6}$

\footnotetext{
1 “Rwanda's Untold Story,” BBC Media Centre, 1 October 2014. https://www.bbc.co.uk/mediacentre/proginfo/2014/39/rwanda (accessed 29 April 2019).

2 https://www.cnlg.gov.rw/index.php?id=80 (accessed 29 April 2019).

3 https://genodynamics.weebly.com/4-things-about-rwanda-1994.html (accessed 11 May 2019).

4 République du Rwanda, Ministère de l'administration locale, du développement communautaire et des affaires sociales, Dénombrement des victimes du génocide, Rapport final, Kigali, April 2004.

${ }^{5}$ République du Rwanda, Recensement Général de la population et de l'habitat au 15 aout 1991, Analyse des résultats, Kigali, 3.

${ }^{6}$ I extrapolate from 15 August 1991 onwards, using a time span of 2.96 so landing at the end of July 1994. I chose the end of July and not the beginning of April since I compare the predicted number of Tutsi with the number of survivors at the end of July. In the beginning of April (time span of 2.64 years), the predicted Tutsi population would instead be 638,000 .
} 
The next step is an estimate of surviving Tutsi. At the end of July 1994, head counting in refugee camps resulted in an estimated 105,000 Tutsi survivors. According to Gérard Prunier $^{7}$ one should add 25,000 survivors that did not go to camps. Human Rights Watch ${ }^{8}$ adds another 20,000 surviving Tutsi in Zaire and Tanzania. This gives a total of 150,000 Tutsi survivors. Subtracting the number of survivors from the projected Tutsi population in July 1994, one obtains an estimate of 493,000 Tutsi deaths, or 76.7 per cent of Tutsi.

In an equation, this calculation looks as follows:

$\left[597,500 \times(1+0.025)^{2.96}\right]-[150,000]=493,000$

Which is a numerical translation of the following:

$\left[\right.$ Tutsi $\left._{t_{0}} \times\left(1+\text { growth }_{t_{1}-t_{0}}\right)^{t_{1}-t_{0}}\right]-\left[\right.$ Tutsi $\left._{t_{1}}\right]=$ Death_toll_Tutsi $i_{t_{1}-t_{0}}$

with $t_{0}$ a point in time before the genocide, and $t_{1}$ a point in time after the genocide, and growt $_{t_{1}-t_{0}}$, the population growth rate under the no-genocide scenario.

All of the numbers in this equation are however up for debate. I start scrutinizing the number of Tutsi as reported in the 1991 census, i.e. Tutsi $i_{t_{0}}$ with $t_{0} 15$ August 1991.

\section{Tutsi $_{t_{0}}$}

Two criticisms have been put forward regarding the number of Tutsi as reported in the 1991 census. $^{9,10,11}$ First, the Habyarimana regime is said to have deliberately underreported the number of Tutsi in order to keep their school and public employment quotas low. Second, to avoid discrimination, and increase their schooling and employment chances, an unknown number of Tutsi registered as Hutu.

\footnotetext{
${ }^{7}$ Gérard Prunier, The Rwanda Crisis: History of a Genocide (London: Hurst \& Company, 1998), 265.

${ }^{8}$ Alison Des Forges, Leave None to Tell the Story: Genocide in Rwanda (New York: Human Rights Watch, 1999), 15.

${ }^{9}$ Prunier, The Rwanda Crisis, 265.

${ }^{10}$ Filip Reyntjens, Pouvoir et droit au Rwanda (Tervuren : Musée Royale de l'Afrique Centrale, 1985), 501-3.

${ }^{11}$ Des Forges, Leave None to Tell the Story, 15.
} 
In 2005 and 2014, I provided evidence for the alleged underreporting of Tutsi in the 1991 census. In $2005,{ }^{12}$ I made a comparison between the 1991 census data and 1990 population data from the local administration of Gikongoro Province. ${ }^{13}$ two sources that were independently collected from each other. The census reported 12.8 per cent Tutsi in the population of Gikongoro, while the local data reported a much higher proportion of Tutsi, 17.5 per cent (amounting to a discrepancy of 37 per cent).${ }^{14}$ Other population characteristics, such as total population size and the sex ratio hardly differed across the two data sources (less than 1 per cent discrepancy), which speaks to the quality of both sources. Underreporting of Tutsi may have taken place in both data sources, but less so in the local population data. ${ }^{15}$ Hence, an underreporting rate of 37 per cent in the census is a lower bound for Gikongoro province. If the extent of underreporting would have been similar in other provinces, the number of Tutsi at the outbreak of the genocide would have been at least 37 per cent higher than the number extrapolated from the 1991 census. In $2014,{ }^{16}$ I demonstrated that the extent of underreporting was however not similar across provinces.

In that year, I obtained local population data for all Rwandan provinces, be it for the year $1987 .{ }^{17}$ When comparing this source with the 1991 census data, I again found that the

\footnotetext{
${ }^{12}$ Marijke Verpoorten, "The Death Toll of the Rwandan Genocide: A Detailed Analysis for Gikongoro Province," Population 60, no. 4 (2005): 401-39.

${ }^{13}$ In February 2003, I was in Gikongoro where I received the local population data for 1990 as well as for 2002 from the statistical unit of Gikongoro Province.

${ }^{14}$ The figure of $17.5 \%$ is derived from information at the sector level, for 117 of the 125 sectors of Gikongoro province. For the eight sectors part of Rwamiko commune, data were missing at the provincial office.

${ }^{15}$ One of the tasks of the local administration of each commune was to file reports on its population four times a year. The nyumbakumi leaders who know each member of the ten-house unit report to the leaders of the cells, who report to the leaders of the sector, and so on. This dense administrative structure records all births, deaths, immigrations and emigrations. Prior to the genocide, in addition to the age and sex, the ethnic identity of every individual was recorded. Since everybody knows each other at the local level, it would have been difficult for Tutsi to deceive the local administration about their true ethnic identity; and whereas census interviewers sent by the central government were not allowed to ask for the respondent's identity card (on which ethnic identity was mentioned), no such restriction was imposed on the local administration. République du Rwanda. Recensement général de la population et de l'habitat au 15 Août, 1991, Résultats définitifs, Kigali, 1994. ${ }^{16}$ Marijke Verpoorten, "Rwanda: why claim that 200,000 Tutsi died in the genocide is wrong", African Arguments, 27 October 2014. https://africanarguments.org/2014/10/27/rwanda-why-davenport-and-stamscalculation-that-200000-tutsi-died-in-the-genocide-is-wrong-by-marijke-verpoorten/ (accessed 29 April 2019).

${ }^{17}$ The data were part of a report called "Recensement administratif de la population Rwandaise durant la période de 1960-1987". I obtained copies of six pages from that report, including the population data as assembled by the local administration for the communes of Kigali, Butare and Gikongoro, as well as an
} 
proportion of Tutsi was considerably larger in the data from the local administration. But, as shown in Table 1, the discrepancy between the two data sources varies widely across the ten Rwandan provinces, going from a five per cent gap in Butare to a 56 per cent gap in Byumba. ${ }^{18}$ On average, the 1987 data indicate a share of 10.63 per cent Tutsi in Rwanda, instead of 8.42 per cent as reported in the 1991 census (corresponding to a 21 per cent gap). I do not consider the 10.63 proportion as perfectly reliable because there could still have been underreporting in the local data, but one can consider 10.63 per cent as a lower bound since there certainly was no over-reporting of Tutsi.

Table 1. comparison of the proportion of Tutsi as reported in the 1991 census and the 1987 local population data, across provinces

\begin{tabular}{lcccc}
\hline & \multicolumn{2}{c}{ Proportion of Tutsi } & percentage point \\
\cline { 2 - 3 } Province & $\begin{array}{c}1991 \text { census } \\
\text { data }\end{array}$ & $\begin{array}{c}\text { 1987 local } \\
\text { population data }\end{array}$ & $\begin{array}{c}\text { percentage } \\
\text { difference }\end{array}$ \\
\hline \hline Butare & 17.3 & 18.3 & 1.0 & $5.4 \%$ \\
Byumba & 1.5 & 3.4 & 1.9 & $56.0 \%$ \\
Cyangugu & 10.5 & 12.9 & 2.4 & $18.6 \%$ \\
Gikongoro & 12.8 & 20.4 & 7.6 & $37.4 \%$ \\
Gisenyi & 2.9 & 3.4 & 0.5 & $15.7 \%$ \\
Gitarama & 9.2 & 11.2 & 2.0 & $17.9 \%$ \\
Kibungo & 7.7 & 10.0 & 2.3 & $22.9 \%$ \\
Kibuye & 14.8 & 19.3 & 4.5 & $23.2 \%$ \\
Kigali & 10.6 & 11.6 & 1.0 & $8.6 \%$ \\
Ruhengeri & 0.5 & 0.6 & 0.1 & $20.4 \%$ \\
\hline Weighted average & 8.4 & 10.6 & 2.2 & $21.0 \%$ \\
\hline \hline
\end{tabular}

Applying 10.63 per cent to the total population reported in the 1991 population census, one reaches a number of 754,713 Tutsi in 1991. Assuming 2.5 per cent population growth, this implies 811,941 Tutsi living in Rwanda at the end of July 1994, under the no-

overview table of the aggregate data by province, all applying to population records from 30 June 1987 . The data can be found on my website (https://www.uantwerpen.be/en/staff/marijke-verpoorten/my-website/rwanda-drc--benin/rwanda/).

${ }_{18}$ The large variation suggests that underreporting not only occurred at the central level, by the national administration. 
genocide scenario. This number would thus be a lower bound, unless of course it can be argued that 2.5 per cent is an exaggerated growth rate.

\section{$\operatorname{Growth}_{t_{1}-t_{0}}$}

The growth rate of 2.5 per cent falls exactly in between the 1.8 per cent low and 3.2 per cent high that have been used in previous studies. The 1.8 per cent low is part of the scenario's on the genodynamics website. ${ }^{19}$ The 3.2 per cent high was used by Gérard Prunier in his 1998 book. ${ }^{20}$ It is tailored to the 3.1 per cent average population growth of the Rwandan population between 1978 and 1991, but does not take into account that population growth likely declined in the early nineties because of the civil war that broke out between the Rwandan Patriotic Front and the then Rwandan government. It neither takes into account that fertility rates were somewhat lower among Tutsi than among Hutu. At least, they were reported to be lower.

According to the 1991 census report ${ }^{21}$, Tutsi women gave birth to less children (Total Fertility Rate $=5.82)$ than Hutu women $(\mathrm{TFR}=7.40)$. The 1.58-TFR difference partly stems from socioeconomic differences between the ethnic groups, but it could also in part stem from underreporting of Tutsi (births). Under-reporting may have been higher in the 1991 census, being carried out in a climate of civil war and great fear among Tutsi. As such, according to the 1991 census, population growth for Tutsi between 1978 and 1991 amounted to merely 1.9 per cent compared to 3.2 per cent for Hutu. In contrast, the local population data revealed a much smaller population growth difference between ethnic groups. In the report with 1987 population data that I obtained, the following is mentioned:

\footnotetext{
${ }^{19}$ https://genodynamics.weebly.com/4-things-about-rwanda-1994.html (accessed 11 May 2019).

${ }^{20}$ Prunier, The Rwanda Crisis, 265.

${ }^{21}$ Government of Rwanda, Service National de Recensement, Ministère du Plan, Recensement Général de la Population et de l'Habitat au 15 Août, 1991, Résultats Définitifs, Kigali, 1994.
} 
On remarque que les pourcentages des ethnies gardent le même rythme de croissance qu'aux années 1980, soit 88,85\% pour l'ethnie HUTU, de 10,63\% pour l'ethnie TUTSI et 0,47\% pour l'ethnie MUTWA au 30/6/1987 contre $88.53 \%$ pour l'ethnie HUTU, 10,94\% pour l'ethnie TUTSI et 0,53\% pour l'ethnie MUTWA au 31 Décembre 1980.

Thus, in the six and a half year period in between December 1980 and June 1987, the share of Tutsi in the population declined with 0.31 percentage points from its 10.94 per cent starting point in 1980. From this, one can derive that, during the period 1980-1987, the Hutu population grew at a rate of 3.2 per cent, while the Tutsi population grew at a 2.7 per cent rate, or 0.8 percentage points higher than the 1.9 per cent that emerges from the population census data.

It is possible that 2.7 per cent still is an underestimation of the growth rate of Tutsi, since there may also have been increased underreporting in the local population data. Thus, I consider the 2.7 per cent growth rate from the local population data as a lower bound for the population growth rate among Tutsi, at least in peace years. Assuming a slowdown of growth during the civil war years, I adjust this downwards to 2.5 per cent.

\section{Tutsi $_{t_{1}}$}

In the baseline estimate above, I assumed 150,000 survivors, which was based on survivor counts by refugee and human rights organization at the end of July 1994. However, in later years, various surveys by the genocide survivor fund, ${ }^{22}$ the Rwandan institute for statistics, ${ }^{23}$

\footnotetext{
${ }^{22}$ FARG (Fonds national pour l'assistance aux victimes les plus nécessiteuses du génocide et des massacres perpétrés au Rwanda).

${ }^{23}$ Government of Rwanda, Service National de Recensement, Recensement des Rescapés du Génocide de 1994: rapport final, Kigali, 2008.
} 
and the gacaca transitional justice system ${ }^{24}$ reached higher estimates of 282,804 (in 1998), 309,368 (in 2006), and 202,000 (in 2005), respectively.

It is possible that these latter numbers are inflated, because - in contrast with the pregenocide years -there were now incentives to self-identify as Tutsi to be illegible for support from the survivors fund. It is also possible that these numbers include Tutsi who escaped ethnic violence in neighbouring countries, in particular DR Congo, as well as Tutsi diaspora who came back from living abroad. We cannot assess the extent of over-reporting, but because there were no incentives to underreport, 300,000 can be taken as a strict upper bound.

Instead of relying on a rough count of all survivors, one could also rely on detailed small-scale studies that have established a survivor rate among subpopulations of Tutsi. For instance, Human Rights Watch estimates that 25 per cent of Tutsi in Butare survived. ${ }^{25}$ Philip Verwimp finds that less than 25 per cent of Tutsi in Kibuye survived, ${ }^{26}$ but more than 50 per cent in Gitarama. ${ }^{27}$ In my 2005 study, I calculate that Tutsi had on average a 25 per cent survival rate in Gikongoro province. Applying a 25 per cent survival rate to the estimated 812,000 at the eve of the genocide, yields 203,000 survivors. A survival rate of 30 per cent would instead mean there were 244,000 survivors. To reach 300,000 survivors, the survival rate would have had to be on average 37 per cent, which seems on the high end considering the 25 per cent survival rate estimated in the three provinces with the highest share of Tutsi (Butare, Kibuye, Gikongoro). I therefore revise the upper bound of survivors downward, and will assume a range of 150,000 to 250,000 survivors.

\footnotetext{
${ }^{24}$ The data was released in 2007 in pdf format on the website of gacaca http://www.inkiko-gacaca.gov.rw/. Government of Rwanda, National service of Gacaca Jurisdiction, Report on Data Collection: Annexes, Tech. rep., Kigali, 2005. The data are discussed in Marijke Verpoorten, "The Intensity of the Rwandan Genocide: Measures from the Gacaca Records," Peace Economics, Peace Science and Public Policy 18 (2012): 1-26.

${ }^{25}$ Des Forges, Leave None, 26

${ }^{26}$ Philip Verwimp, "Death and survival during the 1994 genocide in Rwanda," Population Studies, 58 (2004): 233-45.

${ }^{27}$ Philip Verwimp, "Testing the Double-Genocide Thesis for Central and Southern Rwanda", The Journal of Conflict Resolution 47 (2003): 423-42.
} 
Death_Toll_Tutsi $i_{t_{1}-t_{0}}$

Based on the above, I estimate the death toll among Tutsi. The lower bound estimate is 562,000 , calculated as follows:

$\left[754,713 \times(1+0.025)^{2.96}\right]-[250,000] \cong 562,000$

Assuming instead only 150,000 survivors, the death toll increases to 662,000 :

$\left[754,713 \times(1+0.025)^{2.96}\right]-[150,000] \cong 662,000$

I thus put forward a death toll of 562,000 to 662,000 Tutsi.

\section{How Many Hutu Died?}

In theory, the death toll among Hutu can be derived by subtracting the death toll among Tutsi from the total death toll among Rwandans.

Death_toll $t_{t_{1}-t_{0}}-$ Death_toll_Tutsi $i_{t_{1}-t_{0}}=$ Death_toll_Hutu $t_{t_{1}-t_{0}}$

To estimate the total number of deaths, including both direct and indirect deaths of the conflict cycle, I first estimate the 'missing population' by 2002 . To do so, I rely on the total population as counted in the 1991 and 2002 census, complemented with estimates on in- and -outmigration. ${ }^{28}$

$$
\left[\mathrm{Pop}_{t_{0}} \times\left(1+\text { growth }_{t_{2}-t_{0}}\right)^{t_{2}-t_{0}}\right]-\left[\mathrm{Pop}_{t_{2}}+\mathrm{OMig}_{t_{2}-t_{0}}-\mathrm{IMig}_{t_{2}-t_{0}}\right]=
$$

Missing_Pop $t_{2}-t_{0}$

with Oop $_{t_{0}}$ the population in 1991; growth $t_{t_{2}-t_{0}}$ the growth rate between August

1991 and August 2002 under the no-conflict-mortality scenario; $P o p_{t_{2}}$ the actual population living in Rwanda as counted in August 2002; which is then corrected for out-migration of

\footnotetext{
${ }^{28}$ Filip Reyntjens undertook a similar exercise in 1997, but based on population estimates from various aid organizations. He arrived at a total death toll of 1,141,750 Rwandans by January 1997. Filip Reyntjens, "Estimation de nombre de personnes tuées au Rwanda en 1994 , "in L'Afrique des grands lacs: annuaire 1996/1997, eds. Stefaan Marysse and Filip Reyntjens. (Paris: L'Harmattan, 2012), 179-86.
} 
Rwandans who lived in Rwanda at $\mathrm{t}_{0}\left(+\mathrm{OMig}_{t_{2}-t_{0}}\right)$ and in-migration of Rwandans who lived abroad at $\mathrm{t}_{0}\left(-I M i g_{t_{2}-t_{0}}\right)$. In this equation, only $P o p_{t_{0}}$ and $P o p_{t_{2}}$ are straightforward, corresponding to the counts of 7,099,844 and 8,062,431 Rwandan nationals in the 1991 and 2002 census, respectively. When assuming a growth rate of 2.7 per cent under the noconflict-mortality scenario, $\operatorname{Pop}_{t_{0}} \times\left(1+\text { growth }_{t_{2}-t_{0}}\right)^{t_{2}-t_{0}}$ equals $9,517,518$, or roughly 1.5 million above the actual 8,062,431 count in 2002. Immigrants $\left(I M i g_{t_{2}-t_{0}}\right)$ mainly consist of Rwandan diaspora returning from exile, so-called 'old caseload refugees', which can be assumed to approximate $500,000 .{ }^{29}$ There is no demographic information on outmigration $\left(\right.$ OMig $\left._{t_{2}-t_{0}}\right)$. Assuming - admittedly ad hoc - 500,000 Rwandans abroad, and applying Eq.6 gives approximately 1.5 million 'missing Rwandans' by 2002: $\left[7,099,844 \times(1+0.027)^{11}\right]-[8,062,431+500,000-500,000]=1,455,087 \quad$ (Eq.7) How many of these missing Rwandans are Hutu, and how many are Tutsi? Above I put forward an estimated 562,000 to 662,000 death toll of the 1994 genocide against Tutsi. Suppose 662,000 Tutsi were killed in 1994, then Tutsi would account for approximately 820,000 of the 1.5 million 'missing Rwandans'. This is because a population of 662,000 individuals would have grown to 819,260 over a time span of 8 years:

$\left[662,000 \times(1+0.027)^{8}\right]=819,260$

This implies approximately 635,000 Hutu among the missing Rwandans by 2002 $(1,455,087-819,260=635,827)$. Deriving the death toll among Hutu from 635,000 missing Hutu in 2002 is complicated by the fact that the killings of Hutu were not

\footnotetext{
${ }^{29}$ Above, I assumed that there were approximately 812,000 Tutsi in Rwanda in 1994. From this, one can derive a rough estimate of Tutsi living in exile in 1994 (a similar calculation was followed by Guichaoua, "Le problème des réfugiés et des populations banyarwanda dans la région des Grands Lacs", 1992, p.23). The starting point is a 1956 report from the Belgian colonial administration that put the total population at 2,374,000, and the share of Tutsi at $16.59 \%$, or 394,000. Extrapolating forward to 1994 , relying on a growth rate of $3 \%$, gives 1,210,000 Tutsi. Subtracting 812,000 yields an upper bound of approximately 400,000 Tutsi in exile. By 2002 , the number would have increased to about 500,000 (assuming a 2.7\% growth rate). Other scholars have adopted higher estimates (see e.g. Reyntjens, "Estimation de nombre de personnes tuées au Rwanda en 1994", 179-86); as well as the sensitivity check below.
} 
concentrated in a narrow time period. Taking 1996 as the centre of gravity seems reasonable, since many of the mass killings of Hutu as well as deaths due to disease occurred in DR Congo, in 1996-1997. Calculating backwards to 1996, 635,000 missing Hutu in 2002 yield 542,000 Hutu lives lost, because:

$\left[635,827 /(1+0.027)^{6}\right]=541,896$

As the numbers for Death_toll_Tutsi $i_{t_{1}-t_{0}}$, OMig $_{t_{2}-t_{0}}, I M i g_{t_{2}-t_{0}}$ and growth $_{t_{2}-t_{0}}$ are all up for debate, there is a very wide uncertainty interval around this estimate. For instance, when Death_toll_Tutsi $i_{t_{1}-t_{0}}=562,000$, OMig $_{t_{2}-t_{0}}=200,000$, IMig $_{t_{2}-t_{0}}=$ 700,000 and growth $_{t_{2}-t_{0}}=0.030$, the missing Rwandans in 2002 would number 2,265,000 and the death toll among Hutu would equal 1.3 million. Conversely, when Death_toll_Tutsi $i_{t_{1}-t_{0}}=662,000$, OMig $_{t_{2}-t_{0}}=600,000, I M i g_{t_{2}-t_{0}}=400,000$ and growth $_{t_{2}-t_{0}}=0.025$, there would have been 1,053,000 missing Rwandans in 2002, and a Hutu death toll of $212,000 .^{30}$

Figure 1. Map of 1991-2002 commune-level excess mortality as calculated from excess mortality proxies of the 1991 and 2002 population census

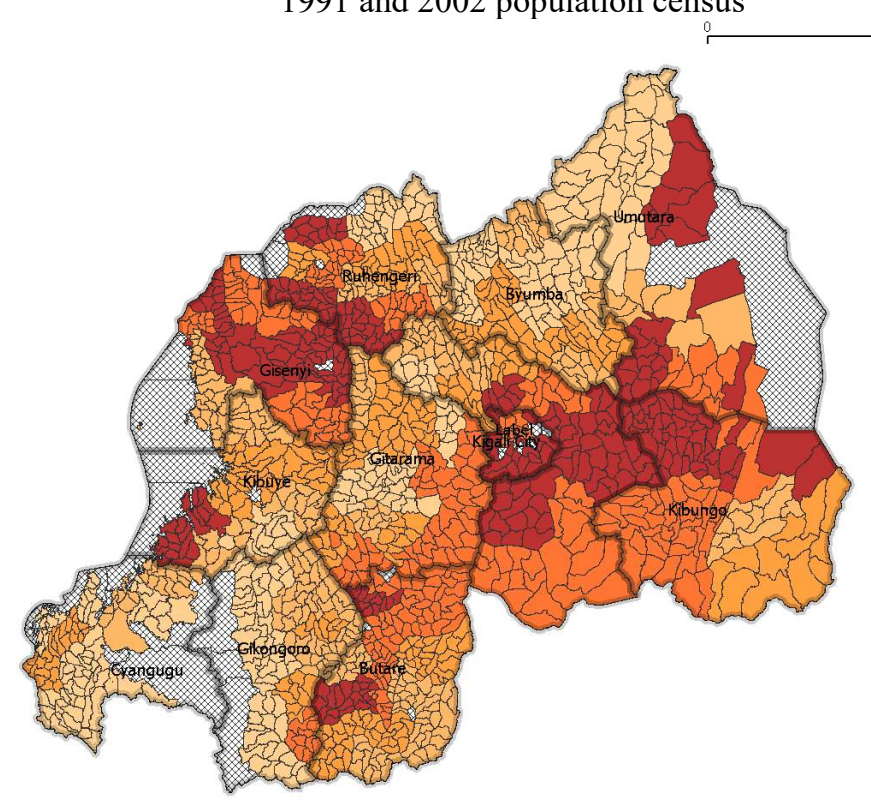

\footnotetext{
${ }^{30}$ On my website (https://www.uantwerpen.be/en/staff/marijke-verpoorten/my-website/rwanda--drc-benin/rwanda/) I provide an excel spreadsheet in which these simulations can be replicated.
} 
Notes: top quintile in darkest shade; map taken from shape file of Rwandan administrative sectors: quintiles calculated at commune level

To narrow down the uncertainty interval, additional information is needed. For instance, an investigation of the spatial pattern of excess mortality in Rwanda provides suggestive evidence of a relatively high mortality among Hutu. In a 2012 publication, ${ }^{31}$ I relied on information from the 1991 and 2002 population census to construct a detailed spatial pattern of wartime excess mortality in Rwanda. ${ }^{32}$ This pattern, visualised in Figure 1, shows high clusters of excess mortality in Butare and Kibuye, where many Tutsi lived. However, it also reveals high excess mortality in the north-western part of the country, where almost no Tutsi lived, as well as in the East, which was the location of heavy fighting between the FAR and the RPA in 1994.

Figure 2. The relation between the 1991 commune-level share of Tutsi and the 1991-2002 commune-level excess mortality index

\footnotetext{
${ }^{31}$ Marijke Verpoorten, "Detecting hidden violence : the spatial distribution of excess mortality in Rwanda", Political geography 31 (2012): 44-56.

32 Concretely, I calculated a weighted average of five excess mortality proxies (1991-2002 differences in (1) mortality of sons, (2) mortality of daughters, (3) widowhood, (4) orphanhood, and (5) 2002 disability due to armed conflict), as well as the distance to a mass grave (to account for bias stemming from the extermination of entire families) by means of principal component analysis. The first principal component provides us with a wartime excess mortality index on a less to more scale for approximately 1500 administrative sectors.
} 


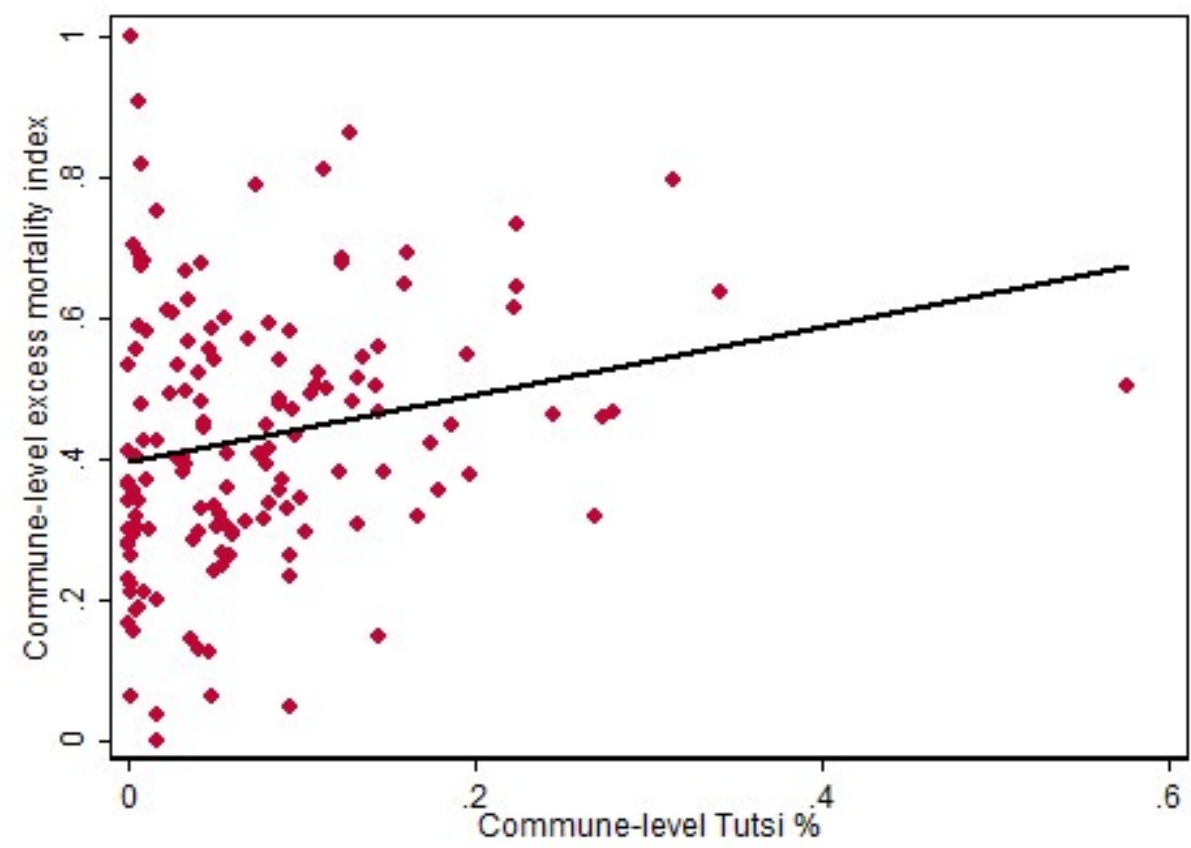

In Figure 2, I present a scatter plot and a linear fit between the commune-level share of Tutsi as reported in the 1991 census (on the horizontal axis) and the commune-level excess mortality index (on the vertical axis). The linear fit slopes upward, indicating a positive correlation between the two measures (correlation coefficient of 0.21 ), and thus relatively high excess mortality in communes with a high pre-genocide Tutsi share in the population. The scatter plot reveals however a lot of variation around the average relation. Most noteworthy, there are many communes with very high excess mortality, where almost no Tutsi lived, mainly in Gisenyi and Ruhengeri province. ${ }^{33}$ By means of a regression analysis, I showed that this excess mortality in part relates to extrajudicial killings in the period 19951998, as described in a series of reports by Amnesty International. ${ }^{34}$ In these north-western provinces, many Hutu also died following the collapse of health care and agricultural production in the mid-nineties. After all, the region served as the corridor of approximately

\footnotetext{
${ }^{33}$ Replicating this scatter plot when dropping migrants from the excess mortality calculation, or when correcting for the proportion of Tutsi using the province-specific information on underreporting as derived from Table 1, yields broadly similar results.

${ }^{34}$ Amnesty International, Rwanda: alarming resurgence of killings (11 August 1996); Rwanda: ending the silence (24 September 1997); Rwanda: civilians trapped in armed conflict (19 December 1997); The hidden violence: 'disappearances' and killings continue (22 June 1998).
} 
one million refugees fleeing to Congo in 1994 and back to Rwanda in 1996/1997, and also experienced a relatively long period of violence as well as important disruptions in economic activities. $^{35}$

\section{Conclusion}

I estimated that 562,000 to 662,000 Tutsi died in the genocidal campaign directed against them, corresponding to a death rate of 70 to 80 per cent among Tutsi in 1994. It is much more difficult to establish how many Hutu died. One estimation method led to a guestimate of 542,000 Hutu lives lost, which amounts to 7.5 per cent of the Hutu population in 1996. The uncertainty interval is however large. I illustrated this by calculating a low of 212,000 and a high of $1,300,000$, relying on different but still fairly plausible assumption. Future research should aim at reducing this uncertainty interval. To contribute to that endeavour, I showed that an investigation of the spatial pattern of excess mortality points to a relatively high death toll among Hutu. It should be born in mind however that this toll includes Hutu killed by Hutu extremists or by the RPA as well as Hutu who died from disease in refugee camps or from dire conditions during wartime. Disentangling the relative weight of these causes of death also remains an important challenge for future research.

\footnotetext{
${ }^{35}$ In this respect, Amnesty International (19 December 1997) reports that, as part of the counterinsurgency strategy, a scorched-earth policy was being carried out in many areas in the Northwest, where homes and fields were being burned. In addition, it is reported that, in an attempt to cut food supplies to armed opposition groups, the RPA prevented farmers from harvesting and marketing their crops.
} 